\title{
Cash Conversion Cycle: Which One and Does It Matter?
}

\author{
Xin Tan (Corresponding Author) \\ Silberman College of Business, Fairleigh Dickinson University \\ 1000 River Rd, Teaneck, NJ 07666, United States \\ Tel: 201-692-7283Ｅ-mail: xtan@fdu.edu \\ Sorin A. Tuluca \\ Silberman College of Business, Fairleigh Dickinson University \\ 285 Madison Avenue, Madison, NJ 07940, United States
}

Received: September 28, 2019 Accepted: October 17, 2019 Published: October 24, 2019

doi:10.5296/ijafr.v9i4.15529 URL: https://doi.org/10.5296/ijafr.v9i4.15529

\begin{abstract}
In the present study, we attempt to investigate the information validity of an important financial metric, the cash conversion cycle (CCC.) A survey of scholarly papers and textbooks reveals that multiple methods to compute the CCC components are employed. Based on a relatively large dataset for six public companies, we explore two of the different methods and their effect on the resulting CCC value. We find that the means of the time series of the two methods over 20 years have only mild statistically significant differences. However, there are important differences in several annual periods for some of the firms analyzed. Since financial managers and financial analysts use the CCC for decision-making, analysis and valuation purposes, the findings of this research represent a warning that the CCC computations might not yield reliable conclusions, as they are dependent on the input used in the calculations.
\end{abstract}

Keywords: Cash conversion cycle, Information validity, Working capital management

\section{Introduction}

Financial statements can help investors, supply chain partners, and other stakeholders of a company analyze its operating performance and financial health. In the last several decades, 
various information technologies and systems, such as Intranet and Enterprise Resource Planning (ERP) have been adopted by businesses around the world to facilitate the bookkeeping and compilation of accounting reports that are the basis for producing the financial statements. As such, those who need the financial information for decision-making can have more up-to-date accounting data than before their adoption. Moreover, large databases of accounting data are available for practitioners and researchers to conduct cross-sectional comparison or longitudinal analysis.

In the present study, we attempt to investigate the information validity of a financial metric, namely cash conversion cycle, using a relatively large dataset about six public companies. Used by financial managers and financial analysts, the cash conversion cycle (CCC) measures the length of time between a firm's cash payment for the purchase of inventory and the end of a firm's operating cycle: the receipt of cash for the sale of goods. In most cases, the inventory purchase and the sale of goods are done on credit. This business practice creates a period in which inventories and receivables would tie up funds. Considering either the financing cost or the opportunity cost of the tied-up funds this period could lead to a considerable financial burden. Monitoring the period and shorten it as much as possible avoids this burden.

The cash conversion cycle was introduced by Richards \& Laughlin (1980) who proposed it as a dynamic indicator in liquidity analysis. As it became part of the financial management education and textbooks it has drawn the attention of many other authors. As such it has been used as a metric for working capital management (see Hutchison, Farris II, \& Anders, 2007; Lind, Pirttilä, Viskari, Schupp, \& Kärri, 2012) and was incorporated in practitioner journals (Cagle, Campbell, \& Jones, 2013). Research was extended to the study of the impact of the CCC on firm's profitability (see Deloof, 2003; Shin \& Soenen, 1998; Yazdanfar \& Öhman, 2014). More recently, the concept has been incorporated in the study of a network of firms in the context of supply chain management (Grosse-Ruyken, Wagner, \& Jönke, 2011; Pavlis, Moschuris, \& Laios, 2018). Given its relevance and importance in financial management and analysis, the cash conversion cycle is a concept included in the CPA and CFA exams, and available in common financial information systems, such as Bloomberg terminals.

Technically a cash conversion cycle can be traced for each item from sourcing of raw materials, to work-in-progress, the sale and payments for finished goods and payment for the purchases needed for production. In reality, it is difficult to track a large number of individual transactions taking place on an on-going basis. Therefore, cash conversion cycle is typically estimated using firm-wide accounting data. In particular, the cash conversion cycle is derived from three components: inventory conversion period, receivable conversion period, and payable deferral period. The following is a generally accepted formula that determines the cash conversion cycle.

\begin{tabular}{|c|}
$\begin{array}{c}\text { Cash } \\
\text { Conversion } \\
\text { Cycle }\end{array}$ \\
Cycle \\
$\begin{array}{c}\text { Inventory } \\
\text { conversion } \\
\text { period }\end{array}$
\end{tabular}$+$\begin{tabular}{c}
$\begin{array}{c}\text { Receivables } \\
\text { conversion } \\
\text { period }\end{array}$ \\
period \\
\hline
\end{tabular}




\section{Macrothink}

International Journal of Accounting and Financial Reporting

ISSN 2162-3082

2019, Vol. 9, No. 4

What is not standardized is the method to compute each component. For instance, while some researchers use average inventory (beginning inventory + ending inventory)/ 2 in estimating the inventory conversion period, others use only the ending inventory for the same estimation. Since the accounting data used for estimation is typically found in a firm's annual report, researchers and practitioners use 360 days or 365 days in the formula for calculating conversion periods (days). With such a wide variety in estimation, the resulting cash conversion cycle is likely to have significant variability for the same firm in the same period. Hence, the comparison across different studies or reports can be distorted.

In this study, we try to investigate the impact of two different estimation methods on the magnitude of the calculated cash conversion cycle. The findings of this research could help academic research as well as practitioners conducting meaningful comparisons of firms' cash conversion cycle in cross-sectional and longitudinal studies.

The rest of paper proceeds as follows: section two reviews the concept of cash conversion cycle and its estimation in the extant literature; section three discusses the specific procedure of data collection and analysis using different estimation procedures to derive the cash conversion cycle; section four presents the findings and their implication of for both researchers and practitioners. The paper concludes with a summary of the paper and directions for future research.

\section{Related Work}

In Richards \& Laughlin (1980), the authors extend the static balance sheet analysis of potential liquidation value coverage and introduce the flow concept of liquidity. As a result, financial statement measures of a firm's operating activity are incorporated into an operating cycle concept, providing "a more appropriate view of liquidity management than does reliance on the current and acid-test ratio indicators of solvency" (p.33). The flow concept of liquidity explicitly recognizes that some working capital components, including account receivable and inventory turnover, are non-instantaneous and unsynchronized. The authors propose the cash conversion cycle as a measurement for the flow concept of liquidity. The cash conversion cycle reflects "the net time interval between actual cash expenditures on a firm's purchase of productive resources and the ultimate recovery of cash receipts from product sales" (p.34). In particular, the authors specify that the cash conversion cycle is equal to the sum of inventory conversion period and receivables conversion period subtracted by the payables deferral period.

As pointed out by Cagle et al. (2013), the cash conversion cycle is a method incorporating time that remedies many of the disadvantages from using the static measures of liquidity, such as current ratio. Recognizing the growing demand for help in managing the cash flow cycle, Hutchison et al. (2007) propose to use the cash conversion cycle as a benchmark to investigate improvement opportunities and a tool in the negotiations with suppliers and customers.

In addition to analyzing firm's liquidity with the cash conversion cycle, some researchers have investigated the impact of cash conversion cycle to a firm's financial performance. For 


\section{Mll Macrothink}

International Journal of Accounting and Financial Reporting

ISSN 2162-3082

2019, Vol. 9, No. 4

instance, Skomorowsky (1988) uses a merchandising company to illustrate how the cash conversion cycle may affect the firm's net income, while Soenen (1993) discusses the impact of the three periods on corporate profitability. In an empirical study, Shin \& Soenen (1998) use a sample of 58,985 firms covering the period 1975-1994 to find a strong negative relation between the length of the firm's cash conversion cycle and its profitability. In a study of large Belgian non-financial firms, Deloof (2003) finds that a firm's profitability can increase by reducing the number of days in receivable conversion period and inventory conversion period. Similar studies have been done on different industries and in different countries, such as the manufacturing sector in Malaysia (Jakpar et al., 2017), the small and medium-sized companies in Italy (Muscettola, 2014), Indian automobile firms (Vijayakumar, 2011), and a listed company in Brazil (Zeidan \& Shapir, 2017). For a more comprehensive review of evaluating the impact of cash conversion cycle on firm performance, please see Lin et al. (2016) and Chang (2018). While these studies treat the cash conversion cycle as an independent variable, the formulas to calculate the three periods are not consistent. This may lead to results that are not comparable in meta-analysis and benchmarking.

Table 1. Different methods to calculate the components of cash conversion cycle

\begin{tabular}{|c|c|c|c|c|}
\hline Reference & Term & $\begin{array}{l}\text { Formula for } \\
\text { RCP }\end{array}$ & $\begin{array}{l}\text { Formula for } \\
\text { ICP }\end{array}$ & Formula for PDP \\
\hline \multicolumn{5}{|c|}{ Ending balance of $\mathrm{AC} / \mathrm{AP} /$ Inventory is used } \\
\hline $\begin{array}{l}\text { (Richards \& } \\
\text { Laughlin, } \\
1980 \text { ) }\end{array}$ & $\begin{array}{l}\text { Cash } \\
\text { conversion } \\
\text { cycle }\end{array}$ & $360 * \mathrm{AC} /$ Sales & $\begin{array}{l}360 * \\
\text { Inventory / } \\
\text { COGS }\end{array}$ & $\begin{array}{l}360 \times \text { (accounts } \\
\text { payable }+ \\
\text { salaries/benefits/payroll } \\
\text { tax) / (Cost of Goods } \\
\text { Sold+ SGA expenses) }\end{array}$ \\
\hline $\begin{array}{l}\text { (Hutchison et } \\
\text { al., 2007) }\end{array}$ & $\begin{array}{l}\text { Cash to Cash } \\
\text { cycle }\end{array}$ & $365 * \mathrm{AC} /$ Sales & $\begin{array}{l}365 * \\
\text { Inventory } \\
/ \text { COGS }\end{array}$ & $365 * \mathrm{AP} / \mathrm{COGS}$ \\
\hline $\begin{array}{l}\text { (Shin \& } \\
\text { Soenen, } \\
1998)\end{array}$ & $\begin{array}{l}\text { Net Trade } \\
\text { Cycle }\end{array}$ & $365 * \mathrm{AC} /$ Sales & $\begin{array}{l}365 * \\
\text { Inventory } \\
\text { /Sales }\end{array}$ & $365 *$ AP /Sales \\
\hline $\begin{array}{l}\text { (Rosenbaum } \\
\text { \& Pearl, } \\
\text { 2009) }\end{array}$ & $\begin{array}{l}\text { Free cash flow } \\
\text { projections }\end{array}$ & $365 * \mathrm{AC} /$ Sales & $\begin{array}{l}365 * \\
\text { Inventory } \\
/ \text { COGS }\end{array}$ & $365 * \mathrm{AP} / \mathrm{COGS}$ \\
\hline \multicolumn{5}{|c|}{ Annual average of $\mathrm{AC} / \mathrm{AP} /$ Inventory is used } \\
\hline $\begin{array}{l}\text { (Berk \& } \\
\text { DeMarzo, } \\
2007)\end{array}$ & $\begin{array}{l}\text { Cash } \\
\text { conversion } \\
\text { cycle }\end{array}$ & $\begin{array}{l}\text { AC / Average } \\
\text { Daily Sales }\end{array}$ & $\begin{array}{l}\text { Inventory / } \\
\text { Average Daily } \\
\text { COGS }\end{array}$ & $\begin{array}{l}\text { AP/ Average Daily } \\
\text { COGS }\end{array}$ \\
\hline $\begin{array}{l}\text { (Graham, } \\
\text { Smart, \& } \\
\text { Megginson, } \\
\text { 2009) }\end{array}$ & $\begin{array}{l}\text { Cash } \\
\text { conversion } \\
\text { cycle }\end{array}$ & $\begin{array}{l}\text { Average } \\
\text { receivable } \\
\text { period }\end{array}$ & $\begin{array}{l}\text { Average age of } \\
\text { inventory }\end{array}$ & $\begin{array}{l}\text { Average payment } \\
\text { period }\end{array}$ \\
\hline $\begin{array}{l}\text { (Ross, } \\
\text { Westerfield, } \\
\text { \& Jaffe, } \\
\text { 1996) }\end{array}$ & $\begin{array}{l}\text { Operating } \\
\text { cycle and cash } \\
\text { cycle }\end{array}$ & $\begin{array}{l}365 * \text { Average } \\
\mathrm{AC} / \text { Sales }\end{array}$ & $\begin{array}{l}365 * \text { Average } \\
\text { inventory / } \\
\text { COGS }\end{array}$ & $\begin{array}{l}365 * \text { Average AP / } \\
\text { COGS }\end{array}$ \\
\hline
\end{tabular}


RCP: Receivable conversion period; ICP: Inventory conversion period; PDP: Payable deferral period; AC: Account Receivables; COGS: Cost of Goods Sold; AP: Account Payables

Table 1 above lists select formulas used in academic journal articles and finance textbooks. It is apparent that some variability exists among these formulas. Initially used in Richards \& Laughlin (1980), salaries/benefits/payroll tax and SGA expenses have been consistently omitted in calculating payables deferral period in later studies and analyses. Another minor difference is in the number of days each year used for the calculation. It seems 365 is more popular than 360 in the formulas. Another difference that warrants further analysis is about the basis of account receivables, payables, and inventory. Some references use ending balance of account receivables, inventories, and account payables in calculating each of the component conversion period while others use the annual averages. It is reasonable to argue that such a difference may result in significant difference in the derived cash conversion cycle. The question is whether such a difference is significant enough to yield different conclusions regarding the working capital management. Our study attempts to answer this question.

\section{Research Method and Findings}

In this research, we attempt to measure the impact of two different formula sets on the calculated cash conversion cycle: one set of formulas uses ending balances and the other set uses annual average.

As mentioned in the above section, we use 365 days and two basis (annual average and ending balance) of account receivable, payable, and inventory to calculate the three components of cash conversion cycle. We give an illustration of deriving the cash conversion cycle by the two different methods using Apple Inc.'s 2006 fiscal year. Table 2 summarizes the financial data and formulas used in the calculation. While both the resulting numbers show negative cash conversion cycles for Apple in 2006, they do have a different magnitude: -59.36 days versus -42.70 days. Given the large amount of working capital tied to Apple's operation, a 17-day difference in cash conversion cycle can mean a significant financial expenses (or savings).

To test the statistical significance of the difference, we retrieved a dataset of accounting data needed for the two methods. We purposefully selected two companies each from three industry sectors that have more than $10 \%$ weight in the SP 500 index. They are Information Technology (Intel and Cisco), Health Care (Johnson \& Johnson and Pfizer), and Industrials (Caterpillar and 3M). We retrieved twenty years (1999-2018) of financial data from Bloomberg and imported it into an Excel workbook for calculation. In this way, the data retrieval and data analysis are streamlined using modern information technologies. For each company in each year (1999-2018), the CCC value using ending balances and the CCC value using annual averages are calculated. This computation results in a pair of CCC values over 20 years for each company. The correlation of each pair data (for one company) range from .86 to .95 . The correlation coefficient, the maximum of the differences, in terms of raw days and percentage (of the average of two values), are reported in Table 3. 
Table 2. Different methods to calculate the Apple Inc.'s cash conversion cycle for 2006

\begin{tabular}{|c|c|c|c|c|c|c|c|c|}
\hline Item & $\begin{array}{l}\text { Beginning } \\
\mathrm{AC}\end{array}$ & $\begin{array}{l}\text { Ending } \\
\mathrm{AC}\end{array}$ & $\begin{array}{l}\text { Beginning } \\
\mathrm{AP}\end{array}$ & $\begin{array}{l}\text { Ending } \\
\mathrm{AP}\end{array}$ & $\begin{array}{l}\text { Beginning } \\
\text { Inventory }\end{array}$ & $\begin{array}{l}\text { Ending } \\
\text { Inventory }\end{array}$ & Sales & COGS \\
\hline $\begin{array}{l}\text { Amount } \\
\text { (in M) }\end{array}$ & 895 & 1,252 & 1,779 & 3,390 & 165 & 270 & 19,315 & 13,717 \\
\hline Calculat & using enc & balar & & & & & & \\
\hline Receival & e conversio & period & $365 \times 125$ & $\div 19315$ & & & 23.66 & ays) \\
\hline Inventor & conversion & eriod & $365 \times 270$ & 13717 & & & $7.18(\mathrm{c}$ & ys) \\
\hline Payable & ferral peric & & $365 \times 339$ & $\div 13717$ & & & 90.21 & ays) \\
\hline Cash cor & ersion cycl & & $23.66+7$ & $8-90.21$ & & & -59.3 & (days) \\
\hline Calcul & asing a & ave & & & & & & \\
\hline Receival & e conversio & period & $365 \times((1)$ & $2+895)$ & $-2) \div 19315$ & & 20.29 & ays) \\
\hline Inventor & conversion & eriod & $365 \times\left(\left(2^{\prime}\right.\right.$ & $+165) \div 2$ & )$\div 13717$ & & 5.79 & ys) \\
\hline Payable & ferral peric & & $365 \times((3)$ & $0+177$ & $2) \div 13717$ & & 68.77 & ays) \\
\hline Cash con & rsion cycl & & $20.29+5$ & $9-68.77$ & & & -42.7 & (days) \\
\hline
\end{tabular}

FY 2006: Beginning date 9/25/2005, Ending date 9/30/2006

Table 3. Descriptive statistics and Wilcoxon signed-rank test results

\begin{tabular}{|c|c|c|c|c|c|c|}
\hline Company & $\begin{array}{l}\text { Correlation } \\
\text { coefficient }\end{array}$ & $\begin{array}{l}\text { Maximum } \\
\text { Difference } \\
\text { (in days) }\end{array}$ & $\begin{array}{l}\text { Maximum } \\
\text { Difference } \\
\text { (in \%) }\end{array}$ & $\begin{array}{l}\mathrm{W} \\
(\mathrm{N}=20)\end{array}$ & $\mathrm{Z}$ & $\begin{array}{l}\text { Reject } \mathrm{H}_{0} \\
(\alpha=0.10, \\
\mathrm{Z} \alpha=1.645 \\
) ?\end{array}$ \\
\hline Intel & 0.93 & 15 & $19 \%$ & -58 & 1.073 & No \\
\hline Cisco & 0.86 & 20 & $38 \%$ & -98 & 1.820 & Yes \\
\hline Pfizer & 0.87 & 132 & $36 \%$ & -6 & 0.103 & No \\
\hline Johnson \& Johnson & 0.95 & 20 & $52 \%$ & -22 & 0.401 & No \\
\hline $3 \mathrm{M}$ & 0.90 & 9 & $9 \%$ & -42 & 0.775 & No \\
\hline Caterpillar & 0.87 & 30 & $14 \%$ & -94 & 1.745 & Yes \\
\hline
\end{tabular}

Since we do not expect such data to be normally distributed, we adopted a non-parametric test, namely Wilcoxon Signed-Rank test, to compare the CCC values derived from the two calculation methods. Wilcoxon Signed-Rank test is a common non-parametric test for paired data (see Lowry, 1998; Rosner, Glynn, \& Lee, 2006). Following the steps in Lowry (1998), 


\section{MIN Macrothink}

International Journal of Accounting and Financial Reporting

ISSN 2162-3082

2019, Vol. 9, No. 4

we calculated the $\mathrm{W}$ (the sum of the signed ranks) and $\mathrm{Z}$ value for each pair in the dataset (see Table 3). The hypothesis testing, with the null hypothesis being no tendency in either direction (the value from one method is always higher or lower than that from the other method), is also included in the table.

We can see from Table 3 that, at $90 \%$ confidence interval, four out of six companies show no statistically significant tendency of the value from one method being always higher than the value from the other method. To see the comparison of values more clearly, we present the values in graphs for each company.

Figure 1 to Figure 6 show in line charts the calculated cash conversion cycle for each of the six companies over the last twenty years. The maximum of such difference percentage over 20 years is reported on the chart.

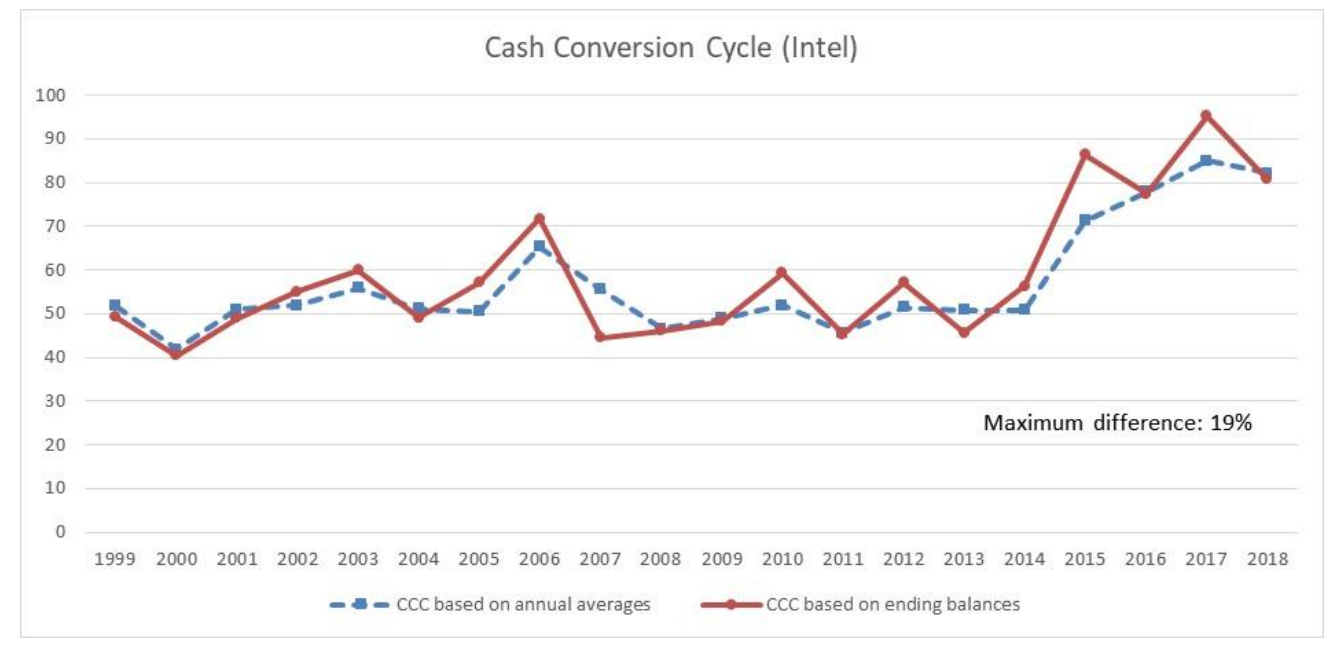

Figure 1. Cash conversion cycle of Intel in information technology sector

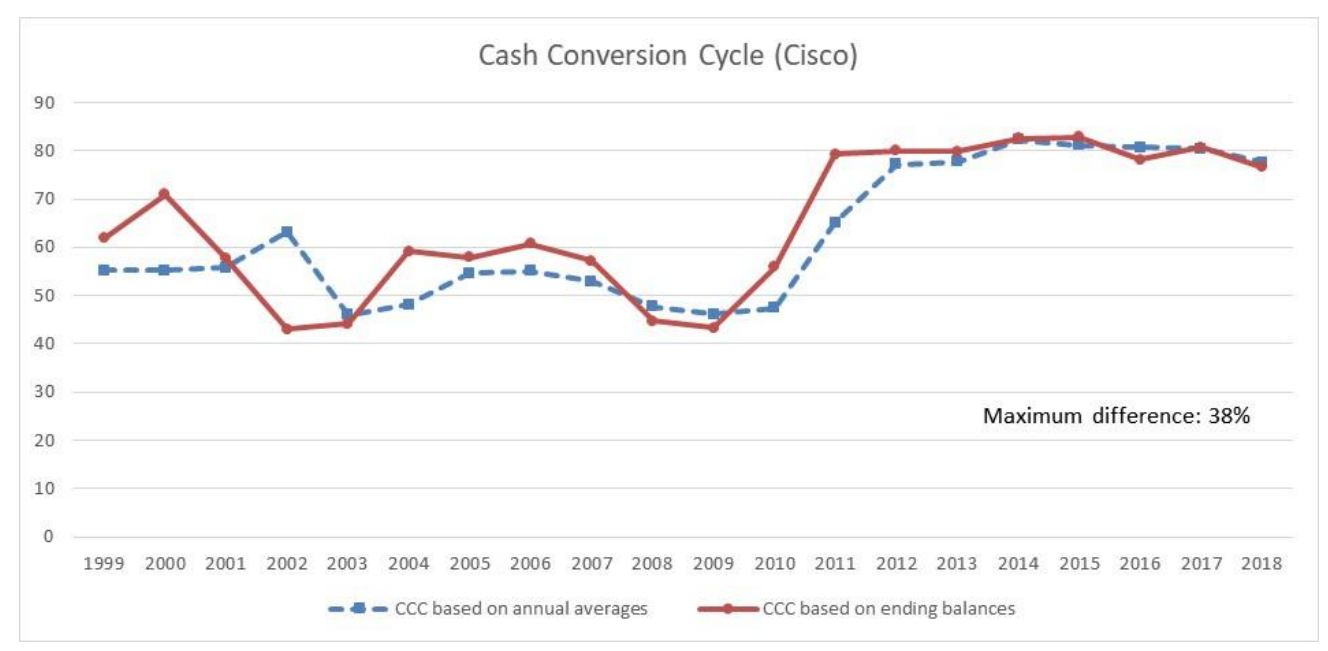

Figure 2. Cash conversion cycle of Cisco in information technology sector 


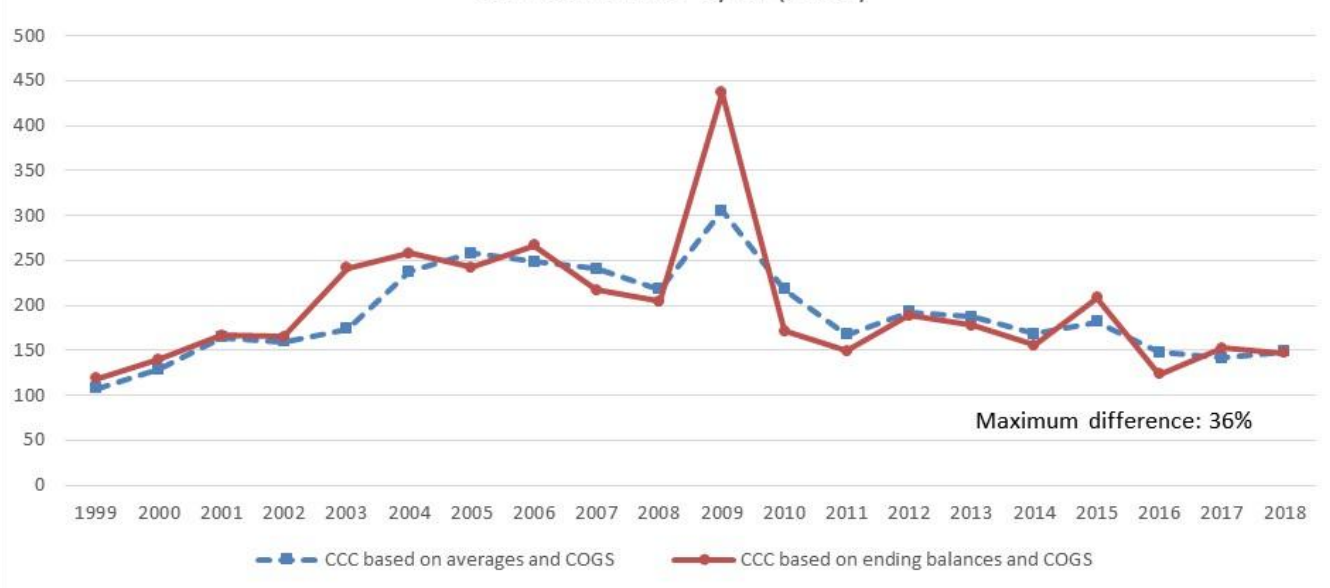

Figure 3. Cash conversion cycle of Pfizer in health care sector

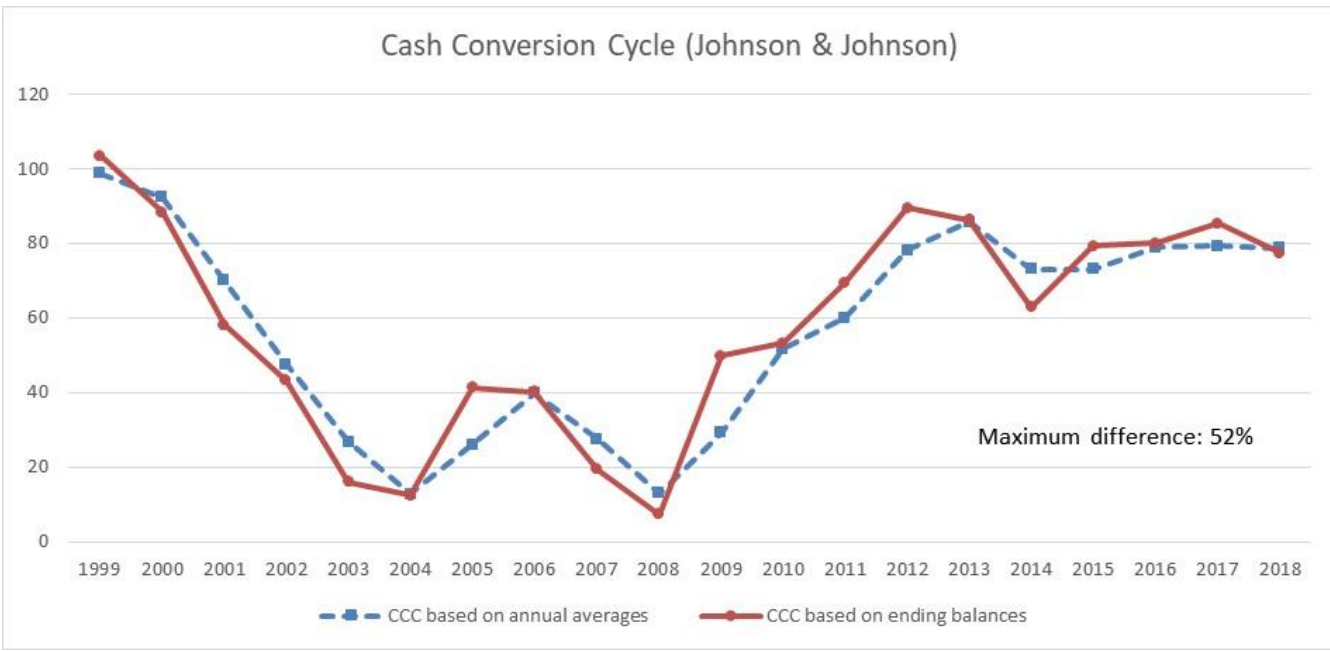

Figure 4. Cash conversion cycle of Johnson \& Johnson in health care sector

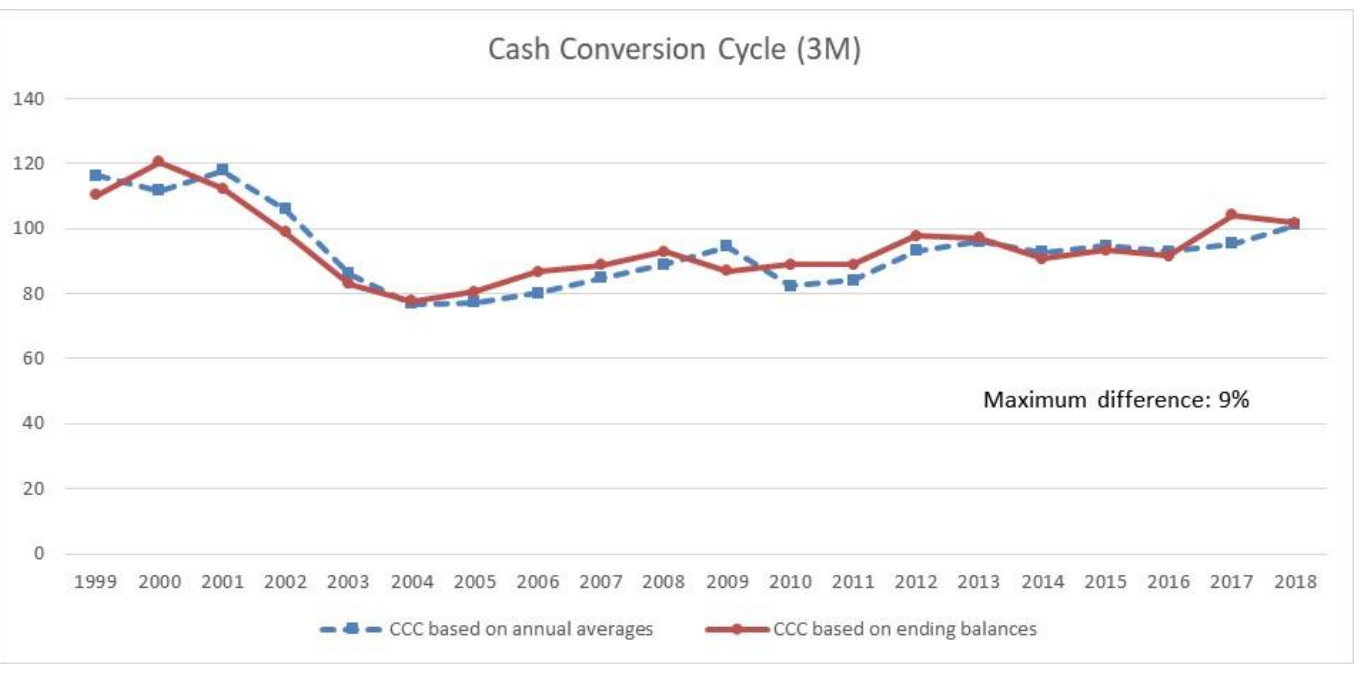

Figure 5. Cash conversion cycle of $3 \mathrm{M}$ in industrials sector 


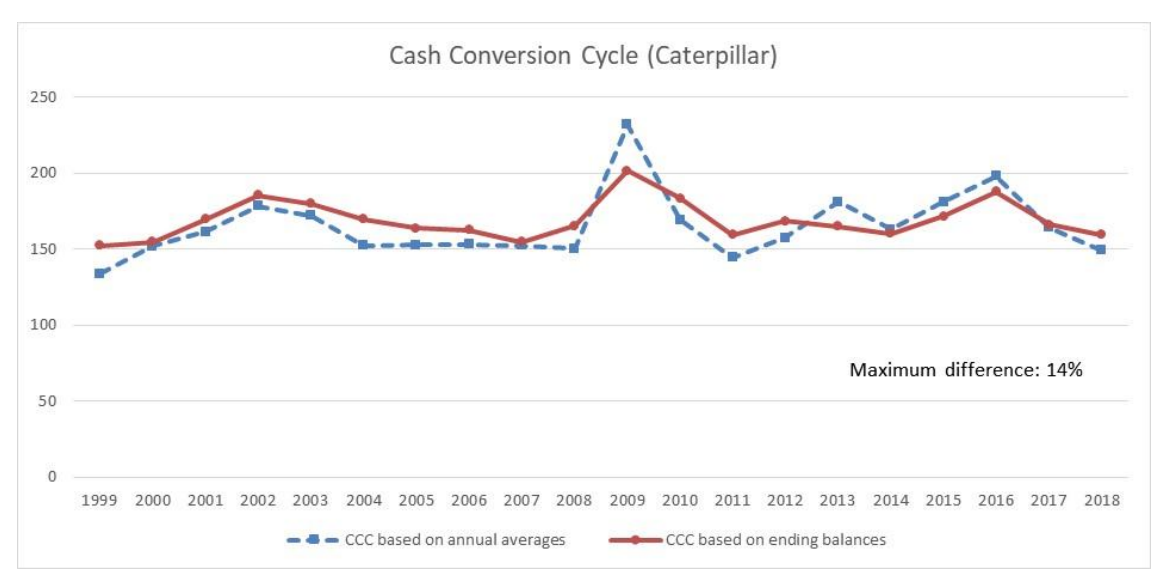

Figure 6. Cash conversion cycle of Caterpillar in industrials sector

\section{Discussion of the Findings}

As shown in the Wilcoxon Signed-Rank test, the majority of companies analyzed as time series had no statistically significant difference in the values derived from the two calculation methods. However, it is still possible that in certain scenarios the results from the two methods will yield different results in longitudinal or comparative analysis. In other words, the variation can distort the longitudinal analysis or cross-sectional comparison of CCC as a gauge of working capital management. In this section, we will discuss the potential impact of the two different methods of calculating cash conversion cycle. Firstly, it can be observed that some CCC values for a certain company do not differ much by the two different methods. For instance, from 2013 to 2016, the CCC values of Cisco are almost the same, as seen in Figure 2. Another example of consistent $\mathrm{CCC}$ values can be found in $3 \mathrm{M}$ for the same period of time (see Figure 5). On the other hand, there are more significant differences than convergences between the CCC values derived by the two different methods. It is not surprising, though, that the lines are smoother for values derived by annual averages than those by ending balances. The impact of the varying results on analyzing the management of working capital is not negligible. We will articulate this issue in two ways.

First, in longitudinal analysis, the result from one method may tell a different story than that from another method. Take Cisco in 1999 to 2005 as an example. As seen in Figure 7, which is a zoomed-in section of Figure 2, the CCC based on ending balances increases from 1999 to 2000, then decreases for two years from 2000 to 2002, flattens from 2002 to 2003, increases from 2003 to 2004, and slightly decreases from 2004 to 2005 . The increase-decrease-decrease-flatten-increase-decrease changes are different from, if not opposite to, those in the dotted line that represents CCC based on average values (account receivable, account payable, and inventory). As a matter of fact, this is not a unique case. The same issue can be found in Intel (2002-2008). Such a varying pattern of change may lead to difference conclusion on the effectiveness of working capital management. After all, shorter cash conversion cycles are considered an indicator of good management (see Jakpar et al., 2017; Lind et al., 2012; Muscettola, 2014) or liquidity analysis (see Garanina \& Belova, 2015; Lin, Lin, Lin, \& You, 2014; Richards \& Laughlin, 1980). The different conclusions will 


\section{MInstitute ${ }^{\text {Mink }}$}

International Journal of Accounting and Financial Reporting

ISSN 2162-3082

further affect the strategies and practices of working capital management. This chain effect makes it crucial for management and researchers to recognize that cash conversion cycle calculated by a different method may show a totally different picture.

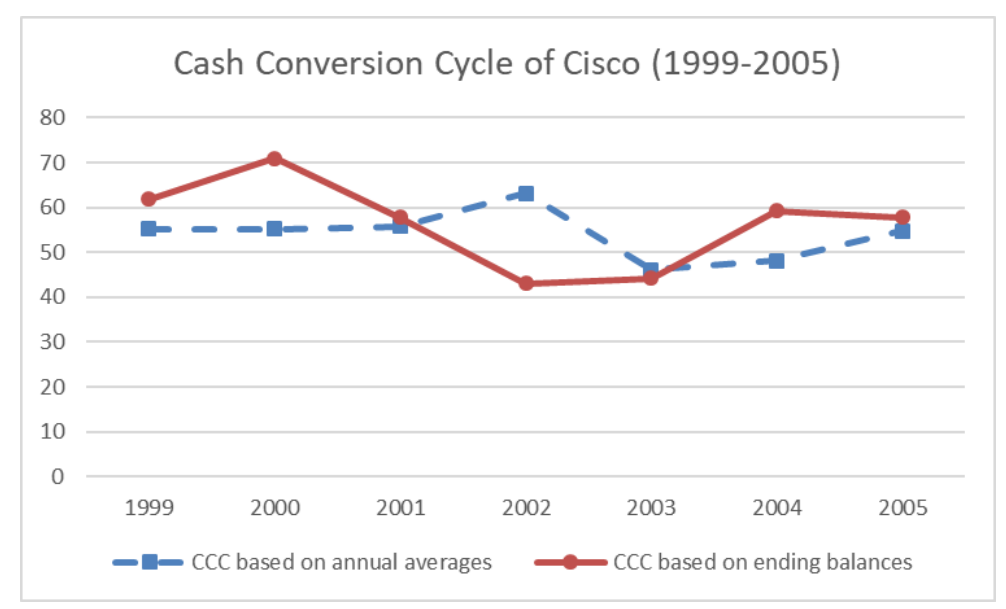

Figure 7. Cash conversion cycle of Cisco in a 6-year period

Secondly, in comparative analysis or benchmarking, a CCC value derived with one method for company A will not be comparable with the one from company $\mathrm{B}$, if a different method was used. To illustrate this issue, we plot the CCC derived by the two methods for both Cisco and Intel on the same chart (Figure 9). It can be seen that in seven years (1999-2002, 2011-2014), Cisco (doted lines) has had a longer cash conversion cycle than Intel (firm lines) no matter what method is used. In five other years (2003, 2006, 2009, 2017 and 2018), both CCC values of Cisco were below those of Intel respectively. In the rest eight years, the comparisons will yield mixed results when different methods are used. For instance, in 2002, Cisco's CCC based on annual averages is higher than both of CCC's of Intel, while Cisco's CCC based on the ending balance is lower than both of Intel's CCC. In contrast, year 2015 shows a higher Intel's CCC if the method using ending balances is adopted. But Intel's CCC would be lower than that of Cisco if the method using annual averages is used. In other words, there is a high probability (40\%) the comparison will show mixed results when the two methods are considered.

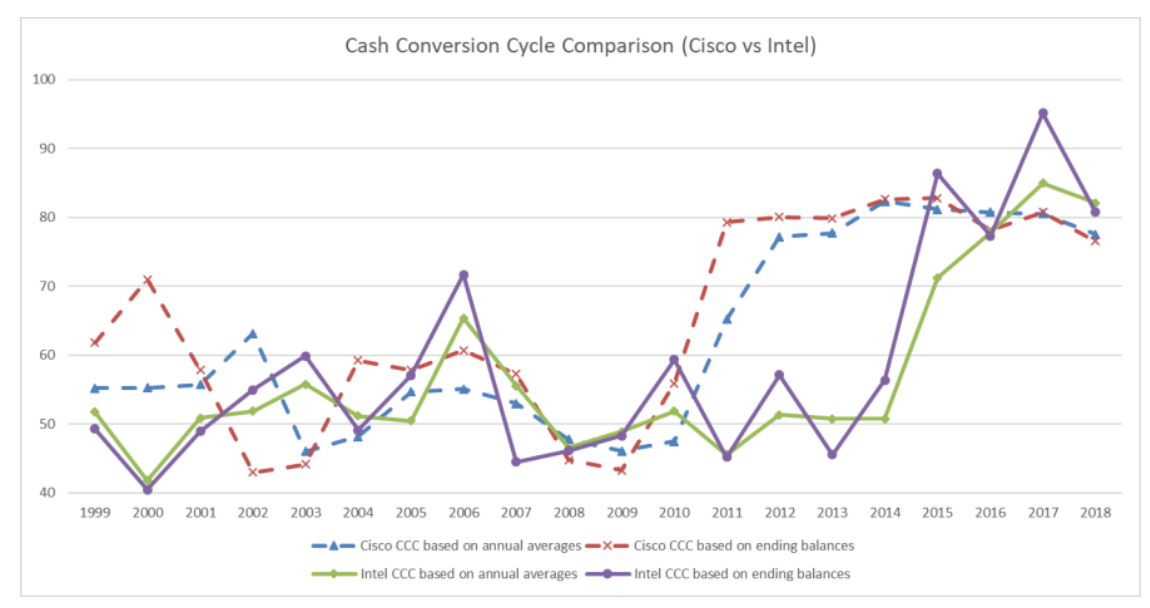

Figure 8. Cash conversion cycle comparison of Cisco and Intel 
If comparing the CCCs among companies in the same industry or sector is already very ambiguous, drawing conclusions on cross-sectional comparisons would be even harder. In addition to longitudinal and comparative analysis, cash conversion cycle as an independent variable has been used to test for its impact on company's profitability (see Deloof, 2003; Jakpar et al., 2017; Shin \& Soenen, 1998) or supply chain efficiency (see Hausman, 2004; Randall \& Theodore Farris, 2009) in some research projects. Researchers and practitioners should be aware that different methods will result in different cash conversion cycle values, having a potentially confounding effect on the research findings.

\section{Conclusion}

In this study, we investigated the issue of cash conversion cycle calculation based on two different methods. Our findings show clear evidence of the variability of a company's cash conversion cycle caused by the different methods. Given the relatively important use of this metric to measure a company's working capital management, liquidity analysis, and even supply chain management, the research community as well as the financial industry practitioners should be mindful of the way the cash conversion cycles were computed before using them for longitudinal or comparative analysis.

There are a few potential limitations in this paper that need to be addressed. First, the data used for analysis are from only six companies. Even though they represent the three largest sectors in S\&P 500, the results may not be generalized to other firms. The purpose of this research is to identify the variability of CCC calculation. To assess the effect size, a statistical analysis of a much larger data set should be conducted. Second, the two methods of CCC calculation used in this study require reliable and readily available financial data. It means the analysis will be hard to achieve for private companies whose financial data are not open to the public. Third, while we identified the variability of $\mathrm{CCC}$ calculation using different methods, how such a difference influences the assessment of CCC's impact on liquidity and working capital management, and eventually the firms' performance is not studied in the present research.

With the availability of modern information technologies, such as Bloomberg Terminals and data analytics software, more financial data can be retrieved and analyzed. Our future research will be in the following directions. First, we would like to identify the causes of variability in cash conversion cycle calculation. Is it industry specific? Do account receivables or inventory have higher impact on the variability? These questions need further investigations. Second, we want to determine which method, annual average or ending balances, provides a more useful assessment. Third, we want to investigate the major contributing factors for changes in a company's cash conversion cycle and assess the economic impact of such changes.

In the end, we wish to re-iterate that cash conversion cycle is just one financial metric that has strengths and limitations. We need to incorporate it with other metrics to gain a more comprehensive understanding of a company's working capital management and liquidity. A deeper understanding about cash conversion cycle is a step toward developing a trustworthy methodology. 


\section{References}

Berk, J. B., \& DeMarzo, P. M. (2007). Corporate finance. Pearson Education.

Cagle, C. S., Campbell, S. N., \& Jones, K. T. (2013). Analyzing liquidity using the cash conversion cycle. Journal of Accountancy, 9(1).

Chang, C. C. (2018). Cash conversion cycle and corporate performance: Global evidence. International Review of Economics \& Finance, 56, 568-581.

Deloof, M. (2003). Does working capital management affect profitability of Belgian firms?. Journal of Business Finance \& Accounting, 30(3-4), 573-588.

Garanina, T. A., \& Belova, O. A. (2015). Liquidity, cash conversion cycle and financial performance: case of Russian companies. Investment Management and Financial Innovations, 12(1), 90-100

Graham, J., Smart, S. B., \& Megginson, W. L. (2009). Corporate finance: Linking theory to what companies do. Nelson Education.

Grosse-Ruyken, P. T., Wagner, S. M., \& Jönke, R. (2011). What is the right cash conversion cycle for your supply chain?. International Journal of Services and Operations Management, 10(1), 13-29.

Hausman, W. H. (2004). Supply chain performance metrics The practice of supply chain management: Where theory and application converge (pp. 61-73). Springer.

Hutchison, P. D., Farris II, M. T., \& Anders, S. B. (2007). Cash-to-cash analysis and management. The CPA Journal, 77(8), 42.

Jakpar, S., Tinggi, M., Siang, T. K., Johari, A., Myint, K. T., \& Sadique, M. (2017). Working capital management and profitability: evidence from manufacturing sector in Malaysia. Journal of Business \& Financial Affairs, 6(2), 1-9.

Lin, W. T., Horng, M. S., \& Chou, J. H. (2016). Relationship of cash conversion cycle and PRGap with firm performance: an empirical study of Taiwanese companies. Investment Management and Financial Innovations, 13(3), 293-299.

Lin, L.-H., Lin, S.-H., Lin, Y.-M., \& You, C.-F. (2014). The analysis of company liquidity a using cash conversion cycle application: evidence from Taiwan. Global Journal of Business Research, 8(5), 97.

Lind, L., Pirttilä, M., Viskari, S., Schupp, F., \& Kärri, T. (2012). Working capital management in the automotive industry: Financial value chain analysis. Journal of Purchasing and Supply Management, 18(2), 92-100.

Lowry, R. (1998). Concepts and applications of inferential statistics. Retrieved from http://vassarstats.net/textbook/index.html

Muscettola, M. (2014). Cash conversion cycle and firm's profitability: An empirical analysis on a sample of 4,226 manufacturing SMEs of Italy. International Journal of Business and Management, 9(5), 25. 


\section{Macrothink}

International Journal of Accounting and Financial Reporting ISSN 2162-3082

Pavlis, N. E., Moschuris, S. J., \& Laios, L. G. (2018). Supply management performance and cash conversion cycle. International Journal of Supply and Operations Management, 5(2), 107-121.

Randall, W. S., \& Theodore Farris, M. (2009). Supply chain financing: using cash-to-cash variables to strengthen the supply chain. International Journal of Physical Distribution \& Logistics Management, 39(8), 669-689.

Richards, V. D., \& Laughlin, E. J. (1980). A cash conversion cycle approach to liquidity analysis. Financial Management, 32-38.

Rosenbaum, J., \& Pearl, J. (2009). Investment banking: valuation, leveraged buyouts, and mergers and acquisitions. John Wiley \& Sons.

Rosner, B., Glynn, R. J., \& Lee, M.-L. T. (2006). The Wilcoxon signed rank test for paired comparisons of clustered data. Biometrics, 62(1), 185-192.

Ross, S. A., Westerfield, R., \& Jaffe, J. F. (1996). Corporate Finance (4th ed.). Irwin/McGraw-Hill.

Shin, H.-H., \& Soenen, L. (1998). Efficiency of working capital management and corporate profitability. Financial Practice and Education, 8, 37-45.

Skomorowsky, P. (1988). The cash to cash cycle and net income. The CPA Journal, 58(12), 84.

Soenen, L. A. (1993). Cash conversion cycle and corporate profitability. Journal of Cash Management, 13, 53-53.

Vijayakumar, A. (2011). Cash conversion cycle and corporate profitability-An empirical enquiry in Indian automobile firms. International Journal of Research in Commerce, IT \& Management, 1(2), 84-91.

Yazdanfar, D., \& Öhman, P. (2014). The impact of cash conversion cycle on firm profitability. International Journal of Managerial Finance, 10(4), 442-452.

Zeidan, R., \& Shapir, O. M. (2017). Cash conversion cycle and value-enhancing operations: Theory and evidence for a free lunch. Journal of Corporate Finance, 45, 203-219.

\section{Copyright Disclaimer}

Copyright for this article is retained by the author(s), with first publication rights granted to the journal.

This is an open-access article distributed under the terms and conditions of the Creative Commons Attribution license (http://creativecommons.org/licenses/by/4.0/) 